\title{
Effects of Wolbachia Infection, Parasitic Order, And Time Interval On The Outcome of Inter-Strain Intrinsic Competition Between Bisexual Strain And Wolbachia-Induced Thelytokous Strain of Egg Parasitoid, Trichogramma Dendrolimi
}

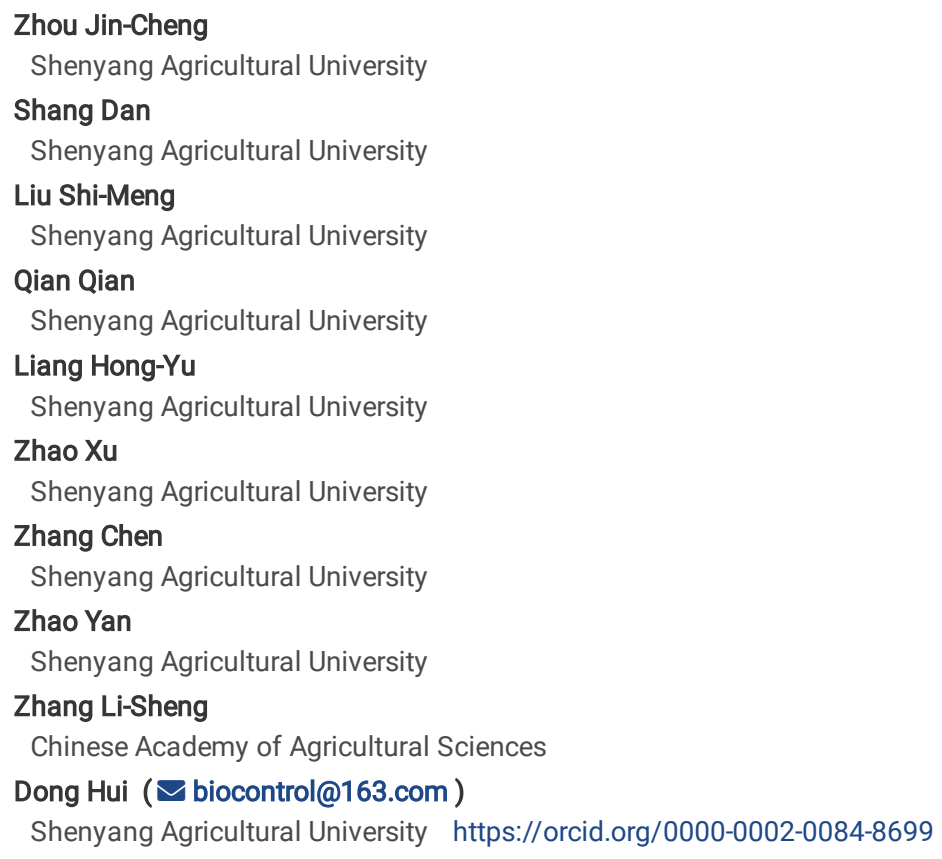

Research Article

Keywords: egg parasitoids, intraspecific competition, superparasitism, Early Acting Competitive Superiority Hypothesis, symbiont Posted Date: January 11th, 2022

DOI: https://doi.org/10.21203/rs.3.rs-981919/v1

License: (c) (1) This work is licensed under a Creative Commons Attribution 4.0 International License. Read Full License 


\section{Abstract}

Parasitoids may deposit a second clutch of eggs on a host that has been parasitized by the same parasitoid species. This is termed "superparasitism". Wolbachia infection increases the superparasitism frequency of Trichogramma females. We investigated the outcome and fitness cost of inter-strain intrinsic competition between Wolbachia-infected thelytokous strain (TDW) and uninfected bisexual strain (TDB) of Trichogramma dendrolimi. To determine the developmental rate of both strains, the size of immature stages of $T$. dendrolimi offspring at different times after parasitization was measured in single parasitism and superparasitism conditions. The results showed increased superparasitism by Wolbachia-infected females compared to uninfected females, regardless of the time interval between oviposition; Trichogramma females were unable to distinguish between host eggs previously parasitized by TDB or TDW females. When the first oviposition was performed by TDB females, the TDB offspring outcompeted TDW offspring deposited later. However, although the TDW offspring was deposited $8 \mathrm{~h}$ earlier than the TDB offspring, it gained no advantage over TDB offspring. Regardless of parasitism conditions, the differences in development rate and time between TDW and TDB offspring were not significant. This study revealed that albeit TDW females presented a higher tendency of superparasitism than TDB females, TDB offspring outcompeted TDW offspring even when the latter was deposited $8 \mathrm{~h}$ earlier. The negative effects of Wolbachia infection on the competitive ability of TDW offspring inside the host eggs were due to offspring's low fitness rather than delayed development.

\section{Introduction}

Trichogramma wasps are a group of egg parasitoid species worldwidely used in biological control programs through inundative release of mass-reared wasps for the fast control of lepidopteran pests in agriculture and forestry (Zhou et al. 2019a; Ferguson et al. 2020; Zang et al. 2020). The infection by the intracellular bacterial symbiont Wolbachia induces parthenogenetic thelytoky of Trichogramma, which allows females to produce almost $100 \%$ female offspring from unfertilized eggs (Huigens et al. 2000; Wu et al. 2020). Thelytokous Wolbachia-infected Trichogramma species may be more suitable in the pest control than their bisexual uninfected counterparts. The infected wasps may have a higher population increase rate as the offspring are almost all female, and the colonization of infected wasps is easier to handle because females can produce generations of fertile offspring without mating under field conditions. Some heritable traits can be fixed in infected strains of Trichogramma because infected offspring females are homozygous diploid, which enables a selection and establishment of optimal lines of Trichogramma in biological control programs (Stouthamer 1999; Ebrahimi et al. 2019; Zhou et al. 2019).

Generally, the resource of suitable hosts fluctuates across seasons and is often limited for certain parasitoid species in field conditions (Lindsey and Stouthamer 2017). For example, female wasps, which are short-lived, prefer to remain longer on a host patch and deposit more eggs on hosts because they may fail to find new hosts (Sheng et al. 2014; Robert et al. 2016a, b). Intraspecific competition may occur when the female wasp deposits a second clutch of eggs on a host that has been parasitized by the same parasitoid species. This is termed "superparasitism" (Van Alphen and Visser 1990; Zhou et al. 2019b). The superparasitism in Trichogramma wasps is expected to be more frequent in the augmentative biological control programs when the inundative number of Trichogramma wasps is released in fields, and in the mass-rearing procedure of Trichogramma production when the host eggs are supplied in excess compared to the number of wasps (Wang et al. 2015; Huang et al. 2017; Zhou et al. 2020).

Interestingly, previous studies indicated that Wolbachia infection in Trichogramma females induced memory loss (Farahani et al. 2017; 2021) and declined host discrimination (Pan et al. 2007; Abrun et al. 2021; Zhang et al. 2021) of infected females compared to their uninfected counterparts. In T. brassicae (Farahani et al. 2015) and T. dendrolimi (Liu et al. 2018), Wolbachia-infected females presented a higher probability of superparasitism than uninfected females. It is worth noting that some pathogens are able to manipulate host wasps to perform superparasitism, which facilitates their horizontal transmission among parasitoid offspring that share the same host. For example, the proclivity of Nasonia vitripennis to superparasitize increased with the presence of a male-killing heritable symbiont, Arsenophonus nasoniae (Parratt et al. 2016). The Leptopilina boulardi Filamentous virus (LbFV) is reported to manipulate the behavior of the parasitoid host $L$. boulardi females, which tend to lay additional eggs in a parasitized host (Patot et al. 2010). In multiparasitism (i.e, the host is parasitized by different parasitoid species) or superparasitism conditions, previous studies have reported inter- and intra-specific horizontal transmission in the parasitoid offspring that shared the same host egg (Schilthuizen and Stouthamer 1997; Huigens et al. 2004; Farokhi et al. 2010; Pan et al. 2011). Thus, it may be an adaptive strategy of Wolbachia that manipulate wasp behaviors to increase wasps' tendency to superparasitize hosts and increase the opportunity for horizontal transmission among Trichogramma offspring (Farahani et al. 2015; Zhou et al. 2019b). However, the superparasitism benefits for intrinsic intraspecific competition remain unknown.

Once the hosts are superparasitized, parasitoid offspring compete for host resources either by scramble competition for the acquisition of shared host nutrition or by contest competition for the monopolization of host resources through excluding competitors. The Early Acting Competitive Superiority Hypothesis predicts that the early acting parasitoid offspring may outcompete the later parasitoid offspring, because either the first active parasitoid larva would have consumed most of the host body fat before pupation (superiority in scramble competition) or the first active larva may kill the eggs or larvae and monopolize the host (superiority in contest competition) (Harvey et al. 2013). Thus, the outcome of the intrinsic competition of parasitoid offspring largely depends on two factors, the order and time lag between the first and second oviposition by the wasps and the time spent on the embryological development.

Considering the short life span and limited host resources in field conditions, the wasps may not hesitate to deposit their eggs in already parasitized hosts. For the Trichogramma host, the tendency of superparasitism in Wolbachia-infected wasps leads to high intraspecific competition with the native bisexual population of Trichogramma in field conditions, especially when Wolbachia-infected wasps are inundatively released in augmentative biological control programs. Additionally, the intraspecific competition has been a serious problem in the mass-rearing procedure of thelytokous Wolbachia-infected strains of Trichogramma, and subsequently affects the quality of offspring wasps. The high tendency for superparasitism of Wolbachia-infected Trichogramma has been reported (Farahani et al. 2015; Liu et al. 2018), and current investigations should focus on Wolbachia-infected and uninfected Trichogramma offspring sharing the same superparasitized host. 
Trichogramma wasps are often found as a facultative gregarious parasitoid. For example, T. dendrolimi females deposit tens of offspring eggs on a larger lepidopteran egg, such as those of Antheraea pernyi (Guérin-Méneville) and Samia cynthia (Drury) (Iqbal et al. 2019, 2020; Wang et al. 2020), but often deposit one offspring egg on small host eggs, such as eggs of rice month, Corcyra cephalonica (Stainton) (Zhang et al. 2010; Wang et al. 2015). It seems impossible to control the condition in which superparasitism occurs in relatively larger host eggs parasitized by Trichogramma wasps because Trichogramma wasps allocate a random number of offspring eggs during oviposition. Furthermore, the ancestry of offspring wasps produced by the first or the second mother is hard to determine.

In this study, the eggs of $C$. cephalonica were chosen because Trichogramma wasps often deposit only one offspring egg per oviposition, which facilitates and increases the accuracy of the superparasitism determination of host eggs. Moreover, we investigated the outcome and fitness cost of inter-strain intrinsic competition between Wolbachia-infected thelytokous strain (TDW) and uninfected bisexual strain (TDB) of T. dendrolimi offspring females. To measure the developmental rate of both $T$. dendrolimi strains in single parasitism and superparasitism conditions, the immature stages of $T$. dendrolimi offspring were photographed at several time intervals after the parasitization. The results may elucidate the carry-over effects of superparasitism behavior of host Trichogramma induced by Wolbachia and provide the reference for the application of Wolbachia-infected thelytokous Trichogramma in biological control programs.

\section{Material And Methods}

\section{Insects}

The Wolbachia-infected thelytokous strain (TDW) and the Wolbachia-uninfected bisexual strain (TDB) of T. dendrolimi were originally isolated from the eggs of Dendrolimus punctatus (Walker) (Lepidoptera: Lasiocampidae) collected from a forest of Chinese red pine, Pinus massoniana Lamb (Coniferales: Pinaceae), located at the southern end of the Changbai Mountains in Huanren County $\left(125^{\circ} 25 \otimes \mathrm{E}, 41^{\circ} 10 \otimes \mathrm{N}\right)$, Liaoning Province, China, on April 16,2017 (Liu et al. 2019). The Wolbachia infection of TDW strain was detected using specific primers (81F: 5囚-TGGTCCAATAAGTGATGAAGAAAC-3】 and 691R: 5囚AAAAATTAAACGCTACTCCA-3囚) for the wsp gene of Wolbachia (Zhou et al. 2020). Thereafter, T. dendrolimi females were reared on C. cephalonica eggs for the next generations. The host insects (C. cephalonica) were reared on a semi-artificial diet (Yang et al. 1990). The fresh host eggs (1 day old without UV irradiation) were glued on an A4 card with Arabic gum. A small square $(1 \mathrm{~cm} \times 1 \mathrm{~cm})$ with a group of 50 eggs was gently cut from the A4 card and used in this experiment. White cards with a group of ca. 300 host eggs with UV-irradiation were used to test the fecundity of offspring females in the experiment.

All organisms were reared in a climate chamber (MLR-352H-PC; Panasonic, Japan) at $25 \pm 1{ }^{\circ} \mathrm{C}$, photoperiod of $16: 8 \mathrm{~h}$ (light: dark), and $75 \pm 5 \%$ relative humidity.

\section{Observation of the immature offspring}

To determine the developmental stage of TDB or TDW offspring in single-parasitized or superparasitized hosts at different times after parasitization, a group of 300 TDB or TDW females were transferred into a glass tube ( $75 \mathrm{~mm}$ length $\times 12 \mathrm{~mm}$ diameter) containing the egg card with ca. 300 host eggs for $10 \mathrm{~min}$. The eggs were cut out individually from the cards and then dissected at $0.5,4,8,12,16,20,24,28,32,36,40,44,48,60,72,96,144$, and $196 \mathrm{~h}$ after the parasitization under a stereomicroscope (SV6; Zeiss, Germany). The single-parasitized and superparasitized host was recognized by the presence of one and two Trichogramma offspring, respectively, in a host egg. To collect the images of the immature stages of Trichogramma offspring with unchanged body size, the samples of Trichogramma offspring were treated with Carnoy's reagent for $2 \mathrm{~h}$. The samples were dehydrated in a gradient of ethanol and glycerol solution according to the procedures described in our previous study (Ning et al. 2019). Then, three samples at each stage were photographed using a camera with a macro lens (SMZ25; Nikon, Japan). The length and width of each sample were measured. All images were edited using the Adobe Illustrator CS6 software.

\section{Experimental protocol}

Two factors were considered in the experiment: the order of parasitism (TDW-TDB: TDW females parasite the host egg first, and TDB females parasite after; TDB-TDW: TDB females parasite the host egg first, and TDW females parasite after) and the time interval between two parasitizations (0.5, 8,16 , and $32 \mathrm{~h}$ ).

A TDB or TDW female (1 day old) was introduced into a Durham tube (30 mm length $\times 6 \mathrm{~mm}$ diameter) containing an egg card with 50 host eggs. The oviposition behavior was observed and recorded under the stereomicroscope (SV6; Zeiss). The oviposition behavior of the female parasitoid was confirmed when single oviposition was detected by the fluctuating abdominal movement (Guo 1993). The location of the parasitized host egg in the egg card was marked with a surgical skin marking pen ( $0.5 \mathrm{~mm}$ tips, T3023; Tondaus, Dongguan, China) immediately after the oviposition behavior occurred. The wasp's behavior was observed continuously for $30 \mathrm{~min}$, after which the wasp was removed. The superparasitized eggs and excess fresh eggs or parasitized eggs were removed gently by a tungsten needle $(0.04 \mathrm{~mm}$ tips). Only 15 fresh eggs and 15 parasitized eggs were kept on the egg card. After $0.5,8,16$, or $32 \mathrm{~h}$ of the first parasitism, the same egg card was supplied to the female of the counterpart strain to parasitize on the host eggs for 30 min. The oviposition behavior and location of each oviposition event were observed and recorded under the stereomicroscope. The host eggs were then maintained in the Durham glass tube until the eggs blackened, which indicated the prepupal stages of Trichogramma offspring (Flanders 1937). The blackened eggs were cut out from the egg card and individually transferred into a new Durham tube for emergence. After wasp emergence, the blackened host eggs were dissected to determine the existence of a dead body of Trichogramma offspring. The superparasitism of the host egg was finally confirmed by the observation of oviposition frequency and the number of offspring wasps allocated in an egg. However, the parasitism type of 46 host eggs failed to be identified because the number of offspring wasps allocated in an egg was not consistent with the oviposition frequency. The development time of each wasp was recorded every $12 \mathrm{~h}$. The emerged female was supplied with an egg card and replaced daily (ca. 300 eggs) for parasitization. The wasps were supplied with a $10 \%$ honey solution via the cotton thread. The 
fecundity of a female individual was recorded by the number of offspring deposited during the life cycle of the female. The longevity of the emerged female wasps was recorded every $12 \mathrm{~h}$ until death. Before DNA extraction, the body size of offspring females was measured as the length of the right hind tibia.

The aborted Trichogramma offspring and the dead offspring wasps were frozen at $-20^{\circ} \mathrm{C}$. The DNA content of a single individual of aborted offspring or emerged wasp was extracted according to the Chelex-100 method (Sumer et al. 2009). Every wasp or aborted offspring was ground in a $1.5 \mathrm{~mL}$ tube containing $50 \mu \mathrm{L} 5 \%$ Chelex-100 mixed with $2.5 \mu \mathrm{L}$ proteinase $\mathrm{K}\left(20 \mathrm{mg} \mathrm{mL}^{-1}\right)$. The tube was maintained at $55^{\circ} \mathrm{C}$ for $1 \mathrm{~h}$, and then at $99{ }^{\circ} \mathrm{C}$ for $10 \mathrm{~min}$. Thereafter, the samples were centrifuged at $15,000 \mathrm{rpm}$ for $10 \mathrm{~min}$. The extracted DNA was stored at $-20^{\circ} \mathrm{C}$. The $\mathrm{CO} /$ sequences of each sample were amplified using PCR according to the procedure described by Liu et al. (2019). The PCR products were sequenced by Invitrogen Trading Co, Ltd. (Shanghai, China). The Trichogramma strain of the offspring was identified using the different CO/ sequences of the TDW strain and TDB strain of T. dendrolimi. The frequencies of inter- and intra-strain-superparasitism were recorded according to the $\mathrm{CO} /$ sequence of the wasps that emerged from a host egg. The survival proportion of TDW or TDB offspring was calculated as the number of emerged wasps from the offspring.

In the experiment, all single-parasitized host eggs by TDB or TDW females were collected as the control groups; the survival proportion, adult longevity, body size, development time, and fecundity of these offspring females were recorded.

\section{Statistical analysis}

The total proportion of superparasitism and the proportion of inter-strain superparasitism of the second-visiting wasps influenced by the time interval and $T$. dendrolimi strain were analyzed using the generalized linear models (GLM) with quasibinomial distribution. The GLM with quasi-Poisson distribution was applied to analyze adult longevity, fecundity, and development time of the offspring as influenced by the order of parasitism, time interval, and $T$.

dendrolimi strain. The GLM with Gaussian distribution was used to analyze the body size of offspring in reference to the order of parasitism, time interval, and T. dendrolimi strain. A logistic growth model was used to analyze the developing rate of offspring body length and body width influenced by $T$.

dendrolimi strain and parasitism type (single parasitism and superparasitism) as a function of development time $(0.5,4,8,12,16,20,24,28,32,36,40,44,48$, $60,72,96,144$, and $196 \mathrm{~h}$ ). The model is given by the following equations:

$$
\begin{aligned}
& y=\frac{k}{1+a e^{-b t},} \\
& T_{1}=\frac{1}{b} \ln \frac{2+\sqrt{3}}{a}, \\
& T_{1}=\frac{1}{b} \ln \frac{2-\sqrt{3}}{a}, \\
& V_{m}=\frac{b k}{4}, \\
& T_{m}=-\frac{\ln a}{b},
\end{aligned}
$$

where $a$ and $b$ are parameters, $k$ is the upper bound of offspring body length or width, $T_{1}$ is the time to germinate, $T_{2}$ is the time of fully grown, $V_{m}$ is the maximum developing rate, and $T_{m}$ is the time of offspring with maximum developing rate (Swishchuk and Wu 2003).

All study analyses were conducted using R software version 4.0.2 (R Development Core Team 2020).

\section{Results}

\section{Superparasitism}

The proportion of superparasitism was significantly affected by $T$. dendrolimi strain $\left(\chi^{2}=82.86, d f=1, P<0.001\right)$ and time interval $\left(\chi^{2}=27.03, d f=3, P<\right.$ 0.001 ), but was not affected by the interaction between $T$. dendrolimi strain and time interval $\left(\chi^{2}=0.82, d f=3, P=0.85\right)$. The proportion of superparasitism by TDW female ( $0.5 \mathrm{~h}$ interval: $64.12 \pm 2.88 \%$; $8 \mathrm{~h}$ interval: $66.97 \pm 2.68 \%$; $16 \mathrm{~h}$ interval: $73.59 \pm 2.56 \%$; $32 \mathrm{~h}$ interval: $56.62 \pm 3.51 \%)$ was significantly higher than that by TDB female ( $0.5 \mathrm{~h}$ interval: $39.50 \pm 4.39 \%, z=4.53, P<0.001 ; 8 \mathrm{~h}$ interval: $38.40 \pm 4.46 \%, z=5.28, P<0.001 ; 16 \mathrm{~h}$ interval: $53.01 \pm 4.29 \%, z=4.18, P<$ $0.001 ; 32 \mathrm{~h}$ interval: $32.30 \pm 4.65 \%, z=3.93, P<0.001)$, regardless of time interval. The proportion of superparasitism by TDW or TDB female at $32 \mathrm{~h}$ interval was significantly lower than that at $16 \mathrm{~h}$ interval (TDW: $z=3.93, P<0.001$; TDB: $z=3.15, P=0.0088$ ), but it was not lower than that at $0.5 \mathrm{~h}$ interval (TDW: $z=$ 1.67, $P=0.34$; TDB: $z=1.12, P=0.68$ ) and 8 h interval (TDW: $z=2.37, P=0.082$; TDB: $z=0.94, P=0.78)$ (Fig. 1-S1).

The proportion of inter-strain superparasitism was not affected by time interval $\left(\chi^{2}=8.01, \mathrm{df}=3, P=0.053\right), T$. dendrolimi strain $\left(\chi^{2}=0.39\right.$, df $\left.=1, P=0.53\right)$, or their interaction $\left(\chi^{2}=1.18, \mathrm{df}=3, P=0.76\right.$ (Fig. 1-S2).

\section{Survival proportion of offspring}


The survival proportion of offspring from inter-strain superparasitized hosts was significantly affected by the interaction of the order of parasitism, $T$. dendrolimi strain, and time interval $\left(\chi^{2}=32.90, \mathrm{df}=3, P<0.001\right)$. When the order of parasitism was TDB-TDW, the survival proportion of TDW offspring (0.5 $\mathrm{h}$ interval: $83.97 \pm 1.06 \%$; $8 \mathrm{~h}$ interval: $83.07 \pm 1.10 \% ; 16 \mathrm{~h}$ interval: $83.02 \pm 1.12 \% ; 32 \mathrm{~h}$ interval: $81.90 \pm 1.16 \%)$ was significantly lower than that of TDB offspring (0.5 h interval: $89.03 \pm 0.71 \%, z=4.08, P<0.001 ; 8 \mathrm{~h}$ interval: $89.72 \pm 0.70 \%, z=4.08, P<0.001 ; 16 \mathrm{~h}$ interval: $90.40 \pm 0.57 \%, z=5.12, P<0.001 ; 32 \mathrm{~h}$ interval: $91.54 \pm 0.52 \%, z=8.43, P<0.001)$, irrespective of the time interval. The survival proportion of TDW offspring was not affected by time interval. The survival proportion of TDB offspring with $32 \mathrm{~h}$ interval was significantly higher $(z=2.88, P=0.021)$ than that with $0.5 \mathrm{~h}$ interval, but not significantly higher than that of $8 \mathrm{~h}(z=2.17, P=0.13)$ and $16 \mathrm{~h}$ intervals $(z=1.50, P=0.44)$ (Fig. 2-S1).

When the order of parasitism was TDW-TDB, the survival proportion of TDB offspring $(88.63 \pm 0.96 \%)$ at $0.5 \mathrm{~h}$ interval was significantly higher than that of TDW offspring $(83.18 \pm 1.51 \%, z=3.13, P=0.0017)$, but the differences were not significant in the offspring at $8 \mathrm{~h}$ (TDB: $86.72 \pm 0.92 \%$; TDW: $84.77 \pm 1.24 \%$; $z=1.23, P=0.22)$ and $16 \mathrm{~h}$ intervals (TDB: $84.46 \pm 1.12 \%$; TDW: $86.26 \pm 1.08 \% ; z=1.15, P=0.25$ ). The survival proportion of TDB offspring (81.44 $\pm 1.39 \%$ ) was significantly lower than that of TDW offspring at $32 \mathrm{~h}$ interval $(87.20 \pm 0.99 \%, z=3.48, P<0.001)$. The survival proportion of TDW offspring was not affected by the time interval. The survival proportion of TDB offspring at $0.5 \mathrm{~h}$ interval was significantly higher than that at $16 \mathrm{~h}(z=2.76, P=0.030)$ and $32 \mathrm{~h}$ intervals $(z=4.36, P<0.001)$ (Fig. 2-S2). In the control groups, the survival proportion of TDB offspring $(91.73 \pm 0.58 \%)$ was significantly higher than that of TDW offspring (83.97 $\pm 0.98 \%, z=4.58, P<0.001)$ (Fig. 2-S3).

\section{Offspring body size}

The body size of offspring female was significantly affected by the interaction of the order of parasitism, T. dendrolimi strain, and time interval $\left(\chi^{2}=147.83\right.$, df $=3, P<0.001)$. When the order of parasitism was TDB-TDW, the body size of TDW female $(0.5 \mathrm{~h}$ interval: $116.09 \pm 1.61 \mu \mathrm{m} ; 8 \mathrm{~h}$ interval: $108.56 \pm 1.31 \mu \mathrm{m} ; 16$ h interval: $101.65 \pm 0.81 \mu \mathrm{m} ; 32 \mathrm{~h}$ interval: $100.97 \pm 1.45 \mu \mathrm{m})$ was significantly smaller than that of TDB female $(0.5 \mathrm{~h}$ interval: $125.30 \pm 0.62 \mu \mathrm{m}, z=4.98, P<$ $0.001 ; 8 \mathrm{~h}$ interval: $127.92 \pm 2.25 \mu \mathrm{m}, z=19.36, P<0.001 ; 16 \mathrm{~h}$ interval: $129.03 \pm 0.54 \mu \mathrm{m}, z=16.37, P<0.001 ; 32 \mathrm{~h}$ interval: $130.58 \pm 1.10 \mu \mathrm{m}, z=29.61, P<$ $0.001)$, irrespective of the time interval. The body size of TDW female at $0.5 \mathrm{~h}$ interval was significantly bigger than that at $8 \mathrm{~h}(z=4.13, P<0.001), 16 \mathrm{~h}(z=$ $8.25, P<0.001)$, and $32 \mathrm{~h}$ intervals $(z=8.54, P<0.001)$. The body size of TDW females at $8 \mathrm{~h}$ interval was significantly bigger than that at $16 \mathrm{~h}(z=3.95, P<$ $0.001)$ and $32 \mathrm{~h}$ intervals $(z=4.29, P<0.001)$. The body size of TDB female at $0.5 \mathrm{~h}$ interval was significantly smaller than that at $32 \mathrm{~h}$ interval $(z=2.93, P=$ $0.018)$, but not significantly smaller than that at $8 \mathrm{~h}(z=1.37, P=0.52)$ and $16 \mathrm{~h}$ intervals $(z=2.10, P=0.15)($ Fig. $3-\mathrm{S} 1)$.

When the order of parasitism was TDW-TDB, the body size of TDW females $(116.50 \pm 0.86 \mu \mathrm{m}$,) was significantly smaller than that of TDB females (123.99 \pm $1.72 \mu \mathrm{m}, z=3.22, P=0.0013)$ at $0.5 \mathrm{~h}$ interval; however, the body size of TDW females at $16 \mathrm{~h}$ interval $(120.61 \pm 0.96 \mu \mathrm{m})$ and $32 \mathrm{~h}$ interval $(125.11 \pm 2.50$ $\mu \mathrm{m})$ was significantly bigger than that of TDW females at $16 \mathrm{~h}(114.67 \pm 0.95 \mu \mathrm{m}, z=2.77, P=0.0055)$ and $32 \mathrm{~h}$ intervals $(106.70 \pm 2.25 \mu \mathrm{m}, z=8.46, P<$ 0.001). The difference in the body size between TDW $(117.39 \pm 0.98 \mu \mathrm{m})$ and TDB $(119.46 \pm 1.22 \mu \mathrm{m})$ females was not significant $(z=0.98, P=0.33)$. The body size of TDW female at $32 \mathrm{~h}$ interval was significantly bigger than that at $0.5 \mathrm{~h}$ interval $(z=3.89, P<0.001)$ and $8 \mathrm{~h}$ interval $(z=3.65, P=0.0015)$, but not significantly bigger than that at $16 \mathrm{~h}$ interval $(z=2.10, P=0.15)$. The body size of TDB females at $0.5 \mathrm{~h}$ interval was significantly bigger than that at $16 \mathrm{~h}$ interval $(z=4.13, P<0.001)$ and $32 \mathrm{~h}$ interval $(z=7.56, P<0.001)$, but not significantly bigger than that at $8 \mathrm{~h}$ interval $(z=2.01, P=0.18)(\mathrm{Fig}$. $3-\mathrm{S} 2)$. In the control groups, the body size of TDW female $(146.93 \pm 2.34 \mu \mathrm{m})$ was significantly smaller than that of TDB female $(154.28 \pm 2.34 \mu \mathrm{m}, z=2.23, P=0.026)$ (Fig. 3-S3).

\section{Offspring fecundity}

The fecundity of offspring female was significantly affected by the interaction of the order of parasitism, $T$. dendrolimi strain, and time interval $\left(\chi^{2}=151.94\right.$, df $=3, P<0.001)$. When the order of parasitism was TDB-TDW, the fecundity of TDW females $(0.5 \mathrm{~h}$ interval: $43.44 \pm 1.87 ; 8 \mathrm{~h}$ interval: $39.38 \pm 1.91 ; 16 \mathrm{~h}$ interval: $31.89 \pm 1.09 ; 32 \mathrm{~h}$ interval: $32.94 \pm 3.39)$ was significantly lower than that of TDB females $(0.5 \mathrm{~h}$ interval: $91.60 \pm 2.45, z=9.92, P<0.001 ; 8 \mathrm{~h}$ interval: $96.50 \pm$ 2.17, $z=11.50, P<0.001 ; 16 \mathrm{~h}$ interval: $97.95 \pm 4.85, z=14.84, P<0.001 ; 32 \mathrm{~h}$ interval: $100.78 \pm 4.66, z=14.63, P<0.001)$, regardless of the time interval. The fecundity of TDW females at $0.5 \mathrm{~h}$ interval was significantly higher than that at $16 \mathrm{~h}(z=3.44, P=0.0033)$ and $32 \mathrm{~h}$ intervals $(z=3.06, P=0.012)$, but not at 8 h interval $(z=1.10, P=0.69)$. The fecundity of TDB females was not significantly influenced by the time interval (Fig. 3-S4).

When the order of parasitism was TDW-TDB, the fecundity of TDW females at $0.5 \mathrm{~h}(39.93 \pm 2.45)$ or $8 \mathrm{~h}$ intervals $(46.33 \pm 2.26)$ was significantly lower than that of TDB females within the same intervals $(86.14 \pm 4.95, z=10.10, P<0.001 ; 87.47 \pm 4.07, z=9.65, P<0.001$, respectively); however, the fecundity of TDW females at $32 \mathrm{~h}$ interval $(70.18 \pm 2.39)$ was significantly higher than that of TDB females in the same interval $(45.69 \pm 1.73, z=6.00, P<0.001)$. The difference was not significant in the fecundity of females at $16 \mathrm{~h}$ interval (TDW: $60.12 \pm 2.69 ;$ TDB: $57.65 \pm 3.12 ; z=0.62, P=0.54$ ). The fecundity of TDW females at $0.5 \mathrm{~h}$ or $8 \mathrm{~h}$ interval was significantly lower than that of TDW females at $16 \mathrm{~h}$ or $32 \mathrm{~h}$ interval; however, the fecundity of TDB females at $0.5 \mathrm{~h}$ or $8 \mathrm{~h}$ interval was significantly higher than that of TDB females at $16 \mathrm{~h}$ or $32 \mathrm{~h}$ interval (Fig. 3-S5). In the control groups, the fecundity of TDW females (102.40 \pm 5.63) was significantly lower than that of TDB females (158.75 $\pm 10.52, z=4.80, P<0.001)$ (Fig. 3-S6).

\section{Offspring longevity}

The longevity of females was significantly affected by the interaction of the order of parasitism, $T$. dendrolimi strain, and time interval $\left(\chi^{2}=43.20\right.$, df $=3, P<$ 0.001). When the order of parasitism was TDB-TDW, the longevity of TDW females $(0.5 \mathrm{~h}$ interval: $5.25 \pm 0.43 \mathrm{~d} ; 8 \mathrm{~h}$ interval: $4.19 \pm 0.38 \mathrm{~d} ; 16 \mathrm{~h}$ interval: $3.89 \pm$ $0.34 \mathrm{~d} ; 32 \mathrm{~h}$ interval: $3.00 \pm 3.31 \mathrm{~d})$ was significantly lower than that of TDB females $(0.5 \mathrm{~h}$ interval: $9.07 \pm 0.58 \mathrm{~d}, z=5.24, P<0.001 ; 8 \mathrm{~h}$ interval: $9.57 \pm 0.62$ $\mathrm{d}, z=7.35, P<0.001 ; 16 \mathrm{~h}$ interval: $9.42 \pm 0.53 \mathrm{~d}, z=8.51, P<0.001 ; 32 \mathrm{~h}$ interval: $10.01 \pm 0.56 \mathrm{~d}, z=10.33, P<0.001)$, regardless of the time interval. The longevity of TDW females at $0.5 \mathrm{~h}$ interval was significantly higher than that at $32 \mathrm{~h}(z=4.27, P<0.001)$, but not significantly higher than that at $8 \mathrm{~h}(z=1.84$, $P=0.26)$ and $16 \mathrm{~h}$ intervals $(z=2.49, P=0.061)$. The longevity of TDB females was not influenced by the time interval (Fig. 4-S1). 
When the order of parasitism was TDW-TDB, the longevity of TDW females at $0.5 \mathrm{~h}(5.13 \pm 0.68 \mathrm{~d})$ or $8 \mathrm{~h}$ intervals (5.50 $\pm 0.64 \mathrm{~d})$ was significantly lower than that of TDB females at $0.5 \mathrm{~h}(8.00 \pm 0.88 \mathrm{~d}, z=2.57, P=0.010)$ or $8 \mathrm{~h}$ intervals $(7.47 \pm 0.77 \mathrm{~d}, z=1.96, P=0.049)$; however, the longevity of TDW females at $32 \mathrm{~h}$ interval $(7.82 \pm 0.79 \mathrm{~d})$ was significantly higher than that of TDB females at the same interval $(4.00 \pm 0.58 \mathrm{~d}, z=3.79, P<0.001)$. The difference was not significant in the longevity of females at $16 \mathrm{~h}$ interval (TDW: $6.29 \pm 0.71 \mathrm{~d}$; TDB: $5.12 \pm 0.64 ; z=1.23, P=0.22$ ). The longevity of TDW females was not influenced by the time interval. The longevity of TDB females at $0.5 \mathrm{~h}(z=3.80, P<0.001)$ or $8 \mathrm{~h}$ intervals $(z=3.50, P=0.0026)$ was significantly higher than that of TDB females at $32 \mathrm{~h}$ interval, but was not higher than that of TDB females at $16 \mathrm{~h}$ interval $(z=2.68, P=0.037 ; z=2.33, P=0.091)$ (Fig. 4-S2). In the control groups, there was no significant difference in the longevity of TDW and TDB females (TDW: $8.35 \pm 0.78 \mathrm{~d} ;$ TDB: $10.45 \pm 0.88 \mathrm{~d} ; z=1.79, P=0.074$ ) (Fig. 4-S3).

\section{Development time of offspring}

The development time of the offspring was not affected by $T$. dendrolimi strain $\left(\chi^{2}=0.26, \mathrm{df}=1, P=0.61\right)$, order of parasitism $\left(\chi^{2}=0.030, \mathrm{df}=1, P=0.86\right)$, and time interval $\left(\chi^{2}=4.86, \mathrm{df}=3, P=0.18\right)$ (Figs. 4-S4, 4-S5, 4-S6).

\section{Developmental Rate Of Offspring}

Logistic growth models showed that the rate of development and upper bound of offspring body length was not different between TDB offspring (single parasitism: $V_{m}=15.82 \mu \mathrm{m} / \mathrm{h}, T_{m}=27.68 \mathrm{~h}, k=555.05 \pm 17.09 \mu \mathrm{m}$; superparasitism: $\left.V_{m}=10.81 \mu \mathrm{m} / \mathrm{h}, T_{m}=24.67 \mathrm{~h}, k=445.99 \pm 16.33 \mu \mathrm{m}\right)$ and TDW offspring (single-parasitism: $V_{m}=15.08 \mu \mathrm{m} / \mathrm{h}, T_{m}=27.93 \mathrm{~h}, k=466.48 \pm 16.71 \mu \mathrm{m}$; superparasitism: $V_{m}=11.20 \mu \mathrm{m} / \mathrm{h}, T_{m}=25.11 \mathrm{~h}, k=459.86 \pm 15.01 \mu \mathrm{m}$ ), regardless of parasitism type. The rate of development and upper bound of the offspring body length in single parasitism was significantly higher than that in superparasitism, regardless of $T$. dendrolimi strain (Table 1; Figs. 5-7).

Table 1

Logistic growth parameters of length and width of TDB or TDW offspring in single parasitism or superparasitism

\begin{tabular}{|c|c|c|c|c|c|c|c|c|c|c|c|c|}
\hline \multirow[t]{3}{*}{ Variables } & \multirow[t]{3}{*}{ Parameters } & \multicolumn{6}{|c|}{ Single parasitism } & \multicolumn{5}{|c|}{ Superparasitism } \\
\hline & & \multicolumn{3}{|l|}{ TDB } & \multicolumn{3}{|l|}{ TDW } & \multicolumn{3}{|l|}{ TDB } & \multicolumn{2}{|l|}{ TDW } \\
\hline & & Estimate $\pm S E$ & $t$ & $\mathbf{P}$ & Estimate $\pm S E$ & $t$ & $\mathbf{P}$ & Estimate $\pm S E$ & $t$ & $\mathbf{P}$ & Estimate $\pm S E$ & $t$ \\
\hline \multirow[t]{7}{*}{ Length } & $a$ & $23.47 \pm 8.72 \mathrm{a}$ & 2.69 & 0.0098 & $19.56 \pm 6.31$ a & 3.10 & 0.0032 & $10.93 \pm 3.54 b$ & 3.09 & 0.0033 & $11.55 \pm 3.39 \mathrm{~b}$ & $\varepsilon$ \\
\hline & $\beta$ & $0.11 \pm 0.014 a$ & 7.99 & $<.001$ & $0.11 \pm 0.012 a$ & 8.62 & $<.001$ & $\begin{array}{l}0.097 \pm 0.014 \\
a\end{array}$ & 7.01 & $<.001$ & $\begin{array}{l}0.097 \pm 0.012 \\
a\end{array}$ & 7 \\
\hline & k & $\begin{array}{l}555.05 \pm 17.09 \\
\text { a }\end{array}$ & 32.47 & $<.001$ & $\begin{array}{l}566.48 \pm 16.71 \\
\text { a }\end{array}$ & 33.89 & $<.001$ & $\begin{array}{l}445.99 \pm 16.33 \\
b\end{array}$ & 27.31 & $<.001$ & $\begin{array}{l}459.86 \pm 15.01 \\
b\end{array}$ & $\varepsilon$ \\
\hline & T1 (h) & 16.13 & - & - & 15.56 & - & - & 11.09 & - & - & 11.59 & - \\
\hline & T2 (h) & 39.24 & - & - & 40.31 & - & - & 38.25 & - & - & 38.63 & - \\
\hline & $V m(\mu m / h)$ & 15.82 & - & - & 15.08 & - & - & 10.81 & - & - & 11.20 & - \\
\hline & $\operatorname{Tm}(\mathrm{h})$ & 27.68 & - & - & 27.93 & - & - & 24.67 & - & - & 25.11 & - \\
\hline \multirow[t]{7}{*}{ Width } & $a$ & $\begin{array}{l}118.01 \pm 67.31 \\
\text { a }\end{array}$ & 1.75 & 0.086 & $\begin{array}{l}85.64 \pm 36.76 \\
\text { a }\end{array}$ & 2.33 & 0.024 & $\begin{array}{l}58.69 \pm 28.87 \\
\text { a }\end{array}$ & 2.03 & 0.048 & $50.29 \pm 21.9 \mathrm{a}$ & 2 \\
\hline & $\beta$ & $0.15 \pm 0.019 a$ & 7.93 & $<.001$ & $0.14 \pm 0.015 a$ & 9.79 & $<.001$ & $0.13 \pm 0.017 a$ & 7.78 & $<.001$ & $0.13 \pm 0.015 a$ & $\varepsilon$ \\
\hline & k & $\begin{array}{l}312.39 \pm 8.35 \\
a\end{array}$ & 37.40 & $<.001$ & $\begin{array}{l}317.16 \pm 7.11 \\
\text { a }\end{array}$ & 44.63 & $<.001$ & b $263.93 \pm 7.86$ & 33.59 & $<.001$ & $\begin{array}{l}263.97 \pm 7.27 \\
\text { b }\end{array}$ & $\varepsilon$ \\
\hline & T1 (h) & 22.55 & - & - & 21.67 & - & - & 20.89 & - & - & 20.10 & - \\
\hline & T2 (h) & 39.74 & - & - & 39.88 & - & - & 40.86 & - & - & 40.46 & - \\
\hline & $V m(\mu m / h)$ & 11.96 & - & - & 11.47 & - & - & 8.70 & - & - & 8.54 & - \\
\hline & $\operatorname{Tm}(\mathrm{h})$ & 31.14 & - & - & 30.78 & - & - & 30.87 & - & - & 30.28 & - \\
\hline
\end{tabular}

Notes: Different uppercase letters indicate the significant difference $(P<0.05)$ among the same parameter in different treatment

Similar to the offspring body length, the development rate and upper bound of the offspring body width was not different between TDB offspring (singleparasitism: $V_{m}=11.96 \mu \mathrm{m} / \mathrm{h}, T_{m}=31.14 \mathrm{~h}, k=312.39 \pm 8.35 \mu \mathrm{m}$; superparasitism: $\left.V_{m}=8.70 \mu \mathrm{m} / \mathrm{h}, T_{m}=30.87 \mathrm{~h}, k=263.93 \pm 7.86 \mu \mathrm{m}\right)$ and TDW offspring (single-parasitism: $V_{m}=11.47 \mu \mathrm{m} / \mathrm{h}, T_{m}=30.78 \mathrm{~h}, k=317.16 \pm 7.11 \mu \mathrm{m}$; superparasitism: $V_{m}=8.54 \mu \mathrm{m} / \mathrm{h}, T_{m}=30.28 \mathrm{~h}, k=263.97 \pm 7.27 \mu \mathrm{m}$ ), regardless of parasitism type. The developing rate and upper bound of the offspring body length in single parasitism was significantly higher than that in superparasitism, regardless of $T$. dendrolimi strain (Table 1; Figs. 5-7).

\section{Discussion}


Similar to previous studies (Farahani et al. 2015; Liu et al. 2018; Zhou et al. 2019b), our results confirmed that Wolbachia-infected females had a tendency for superparasitism when compared to uninfected females, regardless of the time interval of oviposition. Under field conditions, when encountering a depleted patch in which most host eggs are already parasitized, parasitoid females have to decide whether to reject the parasitized hosts or to superparasitize the current hosts. To avoid intra-specific competition, parasitoid wasps label the host with host marking pheromones (HMP) along with oviposition behaviors (Godfray 1994; Hubbard et al. 1999). Newly emerged wasps experience both healthy and parasitized hosts and learn to recognize the HMP, which allows them to distinguish the two. Two hypotheses may explain the tendency of superparasitism of Trichogramma wasps induced by Wolbachia infection: 1) Wolbachiainfected females do not produce HMP (Amat and Bernstein 2009). If Wolbachia-infected females lack HMP, both Wolbachia-infected and uninfected females are expected to more frequently superparasitize on the host eggs that have been parasitized by Wolbachia-infected females. However, our results do not support this hypothesis-there was no difference in the proportion of inter-strain superparasitism between TDB and TDW. In fact, Trichogramma females were unable to distinguish the host eggs previously parasitized by TDB or TDW females. 2) Wolbachia infection in Trichogramma females induce the loss of memory. Some studies showed that the memory retention of Trichogramma wasps is induced by Wolbachia infection. For example, the memory duration is significantly longer in Wolbachia-infected T. brassicae than in their uninfected counterparts (Farahani et al. 2017, 2021; Abrun et al. 2021). Owing to the memory loss of Wolbachia-infected Trichogramma wasps, the wasps are expected to forget cues related to HMP and lose the ability to distinguish healthily and parasitized hosts (Ueno and Tanaka, 1996; Farahani et al. 2017).

Our results showed a higher proportion of superparasitism for both TDW and TDB females at $16 \mathrm{~h}$ interval than at $32 \mathrm{~h}$ interval. Generally, the decision of parasitoid females relies on different cues produced by hosts and conspecific individuals. The rise in superparasitism of wasps over time is dependent upon the state of the hosts (Kishinevsky and Keasar 2015). Some parasitoids prefer recently parasitized hosts than the hosts that have been parasitized for a longer time because the quality of the parasitized hosts is expected to decline along with the development and consumption of the parasitoid offspring (Kishinevsky and Keasar 2015). However, in many other wasps, the tendency for superparasitism increases with the increase in time since the previous oviposition. Parasitoid wasps tend to reject the recently parasitized hosts that carry a clear cue of HMP but may accept the hosts with faded cues that were parasitized much earlier (Nufio and Papaj, 2001). Our results suggested that the decision-making of the wasps was influenced by the breakdown of repellent HMP and the decline in host quality with time. In mass-rearing procedure and field release of Trichogramma wasps, healthy hosts are scarce and rarely encountered when certain host eggs are supplied to a large number of wasps; the cue of HMP and memory of Trichogramma fade overtime when the hosts are exposed to the wasps for a long period; parasitoid females are expected to accept parasitized hosts and then reduce the quality of offspring wasps, which may negatively affect the control efficacy against pests.

The present results partly support the Early Acting Competitive Superiority Hypothesis. Duval et al. (2018) reported that the second clutch of T. euproctidis offspring was overcompeted by the first clutch for tens of hours intervals but gained advantages over the first clutch within $1 \mathrm{~h}$ interval. In this study, when the first oviposition was performed by TDB females, the TDB offspring outcompeted TDW offspring deposited by the later females, which was reflected by the higher survival proportion, extended longevity, bigger body size, and higher fecundity. However, even though the TDW offspring was deposited $8 \mathrm{~h}$ earlier than the later TDB offspring, TDW offspring gained no advantage over the TDB offspring. A potential explanation is that the hatching time of Wolbachia-infected Trichogramma eggs is longer than that of uninfected Trichogramma eggs. The first active larva of uninfected Trichogramma may subsequently consume more resources than infected larva or even kill the later competitor and then monopolize the host resource. For example, Heslin and Merritt (2005) reported that the larvae of $T$. carverae Oatman \& Pinto were able to kill and siphon their siblings. As we known, $T$. dendrolimi larvae have not been reported to initiate aggressive attacks similar to T. carverae larvae. A Previous study reported that approximately $35 \%$ of embryos of infected Trichogramma remained at the mitotic stage even at $48 \mathrm{~h}$ after oviposition, while the embryos of their uninfected counterparts could develop to the cellular blastoderm stage within $6 \mathrm{~h}$ (Tagami et al. 2001). Another study showed that the infected offspring of T. kaykai took half a day longer than uninfected offspring to hatch (Hohmann et al. 2001). In contrast, the differences in the development rate and time between infected and uninfected offspring in the present study were not significant regardless of parasitism conditions. Thus, we suggest that the superiority of TDB to TDW offspring is due to the effects Wolbachia exerted on the fitness of $T$. dendrolimi. The results of the control groups also showed that, in single parasitism, infected offspring presented lower survival proportion, smaller body size, and lower fecundity compared with those of uninfected offspring. Similar results were also found in other Trichogramma species with large bodies (Stouthamer and Luck 1993; Hohmann et al. 2001; Miura and Tagami 2004; Russell and Stouthamer 2011; Zhou et al. 2020). The negative effects of Wolbachia on host fitness may subsequently reduce the competitive ability of infected Trichogramma offspring against uninfected Trichogramma offspring inside the host eggs. Even though Wolbachia-infected T. dendrolimi wasps could not benefit from Wolbachia, Wolbachia may gain more opportunities to spread due to the reduced competitive ability of the infected Trichogramma offspring. In superparasitized or multi-parasitized hosts, uninfected Trichogramma offspring or other parasitoid species may be able to siphon the dead body and excrement of infected Trichogramma offspring. Some solitary parasitoids, such as Telenomus spp, even kill the infected Trichogramma offspring and consume the dead bodies. Then, Wolbachia may be horizontally transmitted to other Trichogramma individuals or individuals of other parasitoid species (Huigens et al. 2004).

In this study, we occasionally observed the repeated stinging of Trichogramma females on a host egg, which is similar to the infanticide behavior described by Duval et al. (2018) in T. euproctidis. However, the females performed this behavior both in healthy host eggs and in parasitized host eggs and deposited a random number of offspring eggs. Thus, it was impossible to determine whether this was the oviposition or infanticide behavior. Moreover, the parasitism type of the host was hard to determine. Studies should investigate in more detail this mechanism to describe the complex parasitic behaviors of Trichogramma in future.

In conclusion, the results partly support the Early-Acting Competitive Superiority Hypothesis. The negative effects of Wolbachia on the competitive ability of infected Trichogramma offspring inside the host eggs were due to the low fitness of the offspring rather than the delay in offspring development. Future studies should focus on the effects of Wolbachia infection on the outcome of inter-strain intrinsic competition of Trichogramma offspring in field conditions to provide insights into the application of Wolbachia-induced thelytokous Trichogramma in biological control programs. 


\section{Declarations}

\section{Acknowledgements}

This research was funded by the Projects of National Natural Science Foundation of China $(32102275,32172476,31972339)$, the Projects of Guizhou Tobacco Corporation (201936, 201937, and 201941), the Major Projects of China National Tobacco Corporation (110202001032 (LS-01)), the Agricultural Science and Technology Innovation Program (CAAS-ZDRW202108), Natural Science Foundation of Liaoning Province (2020-BS-137), and the Fundamental Research Funds for the Universities of Liaoning Province (LR2019061, LJKZ0646). We should thank ELSEVIER Language Editing Services for improving the language.

\section{References}

1. Abrun P, Ashouri A, Duplouy A, Farahani HK (2021). Wolbachia impairs post-eclosion host preference in a parasitoid wasp. Science of Nature $108:$ 1-12. https://doi.org/10.1007/s00114-021-01727-z

2. Amat I, Desouhant E, Bernstein DC (2009). Differential use of conspecific-derived information by sexual and asexual parasitic wasps exploiting partially depleted host patches. Behavioral Ecology and Sociobiology 63: 563-572. https://doi.org/10.1007/s00265-008-0691-4

3. Braig HR, Zhou W, Dobson SL, O'Neill SL (1998). Cloning and characterization of a gene encoding the major surface protein of the bacterial endosymbiont Wolbachia pipientis. Journal of Bacteriology 180: 2373-2378. https://doi.org/10.1128/JB.180.9.2373-2378.1998

4. Duval JF, Brodeur J, Doyon J, Boivin G (2018). Impact of superparasitism time intervals on progeny survival and fitness of an egg parasitoid. Ecological Entomology 43: 310-317. https://doi.org/10.1111/een.12502

5. Ebrahimi V, Ashouri A, Rugman-Jones PF, Javan-Nikkhah M, Lindsey A, Stouthamer R (2019). Using parthenogenesis-inducing Wolbachia for the selection of optimal lines of the egg parasitoid Trichogramma pretiosum for use in biocontrol. Entomologia Experimentalis et Applicata 167: $241-251$. https://doi.org/10.1111/eea.12755

6. Farahani HK, Ashouri A, Abroon P, Pierre JS, Van Baaren J (2021). Wolbachia manipulate fitness benefits of olfactory associative learning in a parasitoid wasp. Journal of Experimental Biology 224: jeb240549. https://doi.org/10.1242/jeb.240549

7. Farahani HK, Ashouri A, Goldansaz SH, Shapiro MS, Pierre JS, Van Baaren J (2017). Decrease of memory retention in a parasitic wasp: an efect of host manipulation by Wolbachia? Insect Science 24: 569-583. https://doi.org/10.1111/1744-7917.12348

8. Farahani KH, Ashouri A, Goldansaz SH, Farrokhi S, Ainouche A, Baaren J (2015). Does Wolbachia infection affect decision-making in a parasitic wasp?. Entomologia Experimentalis et Applicata 155: 102-116. https://doi.org/10.1111/eea.12293

9. Farokhi S, Ashouri A, Huigens M, Verbaarschot P (2010): Horizontal transmission of Wolbachia in Trichogramma wasps (Hym. Trichogrammatidae). Iranian Journal of Plant Protection Science 41: 315-325.

10. Ferguson KB, Kursch-Metz T, Verhulst EC, Pannebakker BA (2020). Hybrid genome assembly and evidence-based annotation of the egg parasitoid and biological control agent Trichogramma brassicae. G3:Genes Genomes Genetics 10: 3533-3540. https://doi.org/10.1534/g3.120.401344

11. Flanders SE (1937). Notes on the life history and anatomy of Trichogramma. Annals of the Entomological Society of America 30: $304-308$. https://doi.org/10.1093/aesa/30.2.304.

12. Godfray HCJ (1994). Parasitoids: behavioral and evolutionary ecology. Princeton University Press.

13. Guo M (1993). Study of parasitizing behaviour of Trichogramma ( $)$-progeny number allocation and sex allocation. Natural Enemies of Insects 15 : $51-59$. https://doi.org/ doi:CNKI:SUN:KCTD.0.1993-02-000.

14. Hoffmann AA, Ratna E, Sgro CM, Barton M, Blacket M, Hallas R, De Garis S, Weeks AR (2007). Antagonistic selection between adult thorax and wing size in field released Drosophila melanogasterindependent of thermal conditions. Journal of Evolutionary Biology 20: $2219-2227$. https://doi.org/10.1111/j.1420-9101.2007.01422.x

15. Hohmann CL, Luck RF, Stouthamer R (2001). Effect of Wolbachia on the survival and reproduction of Trichogramma kaykai Pinto \& Stouthamer (Hymenoptera: Trichogrammatidae). Neotropical Entomology 30: 607-612. https://doi.org/ 10.1590/S1519-566X2001000400015

16. Huang J, Hua HQ, Wang LY, Zhang F, Li YX (2017). Number of attacks by Trichogramma dendrolimi (Hymenoptera: Trichogrammatidae) affects the successful parasitism of Ostrinia furnacalis (Lepidoptera: Crambidae) eggs. Bulletin of Entomological Research 107: 812-819. https://doi.org/ 10.1017/S0007485317000335

17. Hubbard SF, Harvey IF, Fletcher JP (1999). Avoidance of superparasitism: a matter of learning?. Animal Behaviour 57: 11931197. https://doi.org/10.1006/anbe.1999.1085

18. Huigens ME, Luck RF, Klaassen R, Maas M, Timmermans M, Stouthamer R (2000). Infectious parthenogenesis. Nature 405: $178-179$. https://doi.org/10.1038/35012066

19. Huigens ME, de Almeida RP, Boons PAH, Luck RF, Stouthamer R (2004). Natural interspecific and intraspecific horizontal transfer of parthenogenesisinducing Wolbachia in Trichogramma wasps. Proceedings of the Royal Society B-Biological Sciences 271: 509-515. https://doi.org/ 10.1098/rspb.2003.2640

20. Iqbal A, Chen YM, Hou YY, Zhang LS, Desneux N, Zang LS (2019). Factitious host species impact on the outcome of multiparasitism between egg parasitoids. Journal of Pest Science 92: 1261-1269. https://doi.org/10.1007/s10340-019-01122-8

21. Iqbal A, Hou YY, Chen YM, Ali A, Monticelli LS, Desneux N, Zang LS (2020). Impact of Trichogramma parasitoid age on the outcome of multiparasitism in the factitious host eggs of Chinese oak silkworm, Antheraea pernyi. Journal of Pest Science 93: 1347-1357. https://doi.org/10.1007/s10340-020-01239-1 
22. Kishinevsky M, Keasar T (2015). State-dependent host acceptance in the parasitoid Copidosoma koehleri. the effect of intervals between host encounters. Behavioral Ecology and Sociobiology 69: 543-549. https://doi.org/ 10.1007/s00265-014-1865-x

23. Lindsey ARI, Stouthamer R. (2017). Penetrance of symbiont-mediated parthenogenesis is driven by reproductive rate in a parasitoid wasp. PeerJ 5: e3505. https://doi.org/ 10.7717/peerj.3505.eCollection 2017.

24. Liu QQ, Zhang TS, Li CX, Gu JW, Hou JB, Dong H (2018). Decision-making in a bisexual line and a thelytokous Wolbachia-infected line of Trichogramma dendrolimi Matsumura (Hymenoptera: Trichogrammatidae) toward their hosts. Pest Management Science 74: 1720-1727. https://doi.org/ 10.1002/ps.4867

25. Liu QQ, Zhou JC, Chen Z, Ning SF, Duan LJ, Dong H (2019). Co-occurrence of thelytokous and bisexual Trichogramma dendrolimi matsumura (Hymenoptera: Trichogrammatidae) in a natural population. Scientific Reports 9: 17480. https://doi.org/ 10.1038/s41598-019-53992-8

26. Miura K, Tagami Y (2004). Comparison of life history characters of arrhenotokous and Wolbachia-associated thelytokous Trichogramma kaykai Pinto and Stouthamer (Hymenoptera: Trichogrammatidae). Annals of the Entomological Society of America 97: 765-769. https://doi.org/10.1603/00138746(2004)097[0765:COLHCO]2.0.CO;2

27. Ning SF, Zhou JC, Liu QQ, Zhao Q, Dong H (2019). Gradual, temperature-induced change of secondary sexual characteristics in Trichogramma pretiosum infected with parthenogenesis-inducing Wolbachia. PeerJ 7: e7567. https://doi.org/10.7717/peerj.7567

28. Nufio CR, Papaj DR (2001). Host marking behavior in phytophagous insects and parasitoids. Entomologia Experimentalis et Applicata 99: $273-293$. https://doi.org/ 10.1046/j.1570-7458.2001.00827.x

29. Pan XH, He YR (2011) Horizontal Transfer of Wolbachia between Trichogramma pretiosum and T. confusum. Acat Agriculturae Boreali-Occidentalis Sinica 20: 186-188. https://doi.org/CNKI:SUN:XBNX.0.2011-04-041.

30. Pan XH, He YR, Chen KW, Pan F, Pan M. (2007). Effect of Wolbachia infection on longevity, fecundity and olfactory response of Trichogramma confusum (Hymenoptera: Trichogrammatidae). Acta Entomologica Sinica 50: 207-214. https://doi.org/10.16380/j.kcxb.2007.03.001.

31. Parratt SR, Frost CL, Schenkel MA, Rice A, Hurst GDD, King KC (2016). Superparasitism Drives Heritable Symbiont Epidemiology and Host Sex Ratio in a Wasp. Plos Pathogens 12: e1005629. https://doi.org/10.1371/journal.ppat.1005629

32. Patot S, Martinez J, Allemand R, Gandon S, Varaldi J, Fleury F (2010). Prevalence of a virus inducing behavioural manipulation near species range border. Molecular Ecology 19: 2995-3007. https://doi.org/10.1111/j.1365-294X.2010.04686.x

33. R Development Core Team. (2020). R: A language and environment for statistical computing. R Foundation for Statistical Computing, Vienna, Austria. URL https://www.R-project.org/.

34. Robert FA, Brodeur J, Boivin G (2016a). Patch exploitation strategies of parasitoids under indirect intra-and inter-specific competition. Ecological Entomology 41: 590-598. https://doi.org/10.1111/een.12328

35. Robert FA, Brodeur J, Boivin G (2016b). Patch exploitation by non-aggressive parasitoids under intra-and interspecific competition. Entomologia Experimentalis et Applicata 159: 92-101. https://doi.org/10.1111/eea.12429

36. Russell JE, Stouthamer R (2011). The genetics and evolution of obligate reproductive parasitism in Trichogramma pretiosum infected with parthenogenesis-inducing Wolbachia. Heredity 106: 58-67. https://doi.org/10.1038/hdy.2010.48

37. Schilthuizen MO, Stouthamer R (1997). Horizontal transmission of parthenogenesis-inducing microbes in Trichogramma wasps. Proceedings of the Royal Society B-Biological Sciences 264: 361-366. https://doi.org/10.1098/rspb.1997.0052

38. Sheng S, Feng S, Meng L, Li BP (2014). Departure mechanisms for host search on high density patches in the parasitoid Meteorus pulchricornis (Wesmael) (Hymenoptera: Braconidae). Journal of Insect Science 14: 1-5. https://doi.org/ 10.1093/jisesa/ieu067

39. Stouthamer R (1993). The use of sexual versus asexual wasps in biological control. Entomophaga 38: 3-6. https://doi.org/10.1007/BF02373133.

40. Stouthamer R, Breeuwer JA, Hurst GD (1999). Wolbachia pipientis: microbial manipulator of arthropod reproduction. Annual Review of Microbiology 53: 71-102. https://doi.org/10.1146/annurev.micro.53.1.71

41. Sumer F, Tuncbilek AS, Oztemiz S, Pintureau B, Rugman-Jones P, Stouthamer R (2009). A molecular key to the common species of Trichogramma of the Mediterranean region. BioControl 54: 617-624. https://doi.org/10.1007/s10526-009-9219-8

42. Swishchuk A, Wu J (2003). Logistic Growth Models. Springer Netherlands.

43. Tagami Y, Miura K, Stouthamer R (2001). How does infection with parthenogenesis-inducing Wolbachia reduce the fitness of Trichogramma? Journal of Invertebrate Pathology 78: 267-271. https://doi.org/10.1006/jipa.2002.5080

44. Takada Y, Kawamura S, Tanaka T (2001). Host preference of Trichogramma dendrolimi (Hymenoptera :Trichogrammatidae) on its native host, Mamestra brassicae (Lepidoptera: Noctuidae) after 12 continuous generations on a factitious host. Applied Entomology and Zoology 36: $213-218$. https://doi.org/10.1303/aez.2001.213

45. Ueno T, Tanaka T (1996). Self-host discrimination by a parasitic wasp: the role of short-term memory. Animal Behaviour 52: $875-883$. https://doi.org/10.1006/anbe.1996.0235

46. Van Alphen JJ, Visser ME (1990). Superparasitism as an adaptive strategy for insect parasitoids. Annual Review of Entomology $35: 59-79$. https://doi.org/10.1146/annurev.en.35.010190.000423

47. Wang LY, Huang J, Dong XY, Zhang F, Li YX (2015). Superparasitism and ontogeny of two Trichogramma species on Corcyra cephalonica (Stainton). Chinese Journal of Biological Control 31: 481-486. https://doi.org/10.16409/j.cnki.2095-039x.2015.04.006.

48. Wang Y, Zou ZP, Hou YY, Yang XB, Wang S, Dai HJ, Xu YY, Zang LS. (2020). Manually-extracted unfertilized eggs of Chinese oak silkworm, Antheraea pernyi, enhance mass production of Trichogramma parasitoids. Entomologia Generalis 40: 397-406. https://doi.org/10.1127/entomologia/2020/1060 
49. Wu X, Lindsey A, Chatterjee P, Werren JH, Stouthamer R, Yi SV (2020). Distinct epigenomic and transcriptomic modifications associated with Wolbachiamediated asexuality. PLoS Pathogens 16: e1008397. https://doi.org/ 10.1371/journal.ppat.1008397

50. Yang CC, Wang JL, Zhang J (1990). Screening the diet prescription for rice moth rearing. Journal of Shenyang Agricultural University $21: 48-52$. https://doi.org/CNKI:SUN:SYNY.0.1990-01-008.

51. Zang LS, Wang S, Zhang F, Desneux N (2020). Biological Control with Trichogramma in China: History, Present Status, and Perspectives. Annual Review of Entomology 66: 463-484. https://doi.org/10.1146/annurev-ento-060120-091620

52. Zhang ZT, Ying M, Zhou JC, Dong H (2021). Effects of acclimatization to the extracts from target pest on host preference of Trichogramma dendrolimi. Chinese Journal of Biological Control 37: 70-76. https://doi.org/10.16409/j.cnki.2095-039x.2021.01.002

53. Zhang YF, Song QT, Zhang F, Li YX (2010). Comparison of superparasitism and suitability to superparasitism between Trichogramma ostriniae and T. dendrolimi. Chinese Journal of Biological Control 26: 377-384. https://doi.org/10.16409/j.cnki.2095-039x.2010.04.001.

54. Zhou JC, Dong QJ, Zhang TS, Duan LJ, Ning SF, Liu QQ, Li YY, Li CX, Dong H (2019a). Effect of wind time on the dispersal capacity of Trichogramma dendrolimi Matsumura (Hymenoptera Trichogrammatidae). Journal of Asia-Pacific Entomology 22: 742-749.

https://doi.org/ 10.1016/j.aspen.2019.06.001

55. Zhou JC, Li YY, Liu QQ, Ning SF, Che WN, Dong H (2019b). Effects of temperature and superparasitism on quality and characteristics of thelytokous Wolbachia-infected Trichogramma dendrolimi Matsumura (Hymenoptera: Trichogrammatidae) during mass rearing. Scientific Reports 9: 18114. https://doi.org/ 10.1038/s41598-019-54719-5.

56. Zhou JC, Liu QQ, Wang QR, Ning SF, Che WN, Dong H (2020). Optimal clutch size for quality control of bisexual and Wolbachia-infected thelytokous lines of Trichogramma dendrolimi Matsumura (Hymenoptera: Trichogrammatidae) mass reared on eggs of a substitutive host, Antheraea pernyi GuerinMeneville (Lepidoptera: Saturniidae). Pest Management Science 76: 2635-2644. https://doi.org/10.1002/ps.5805

\section{Figures}
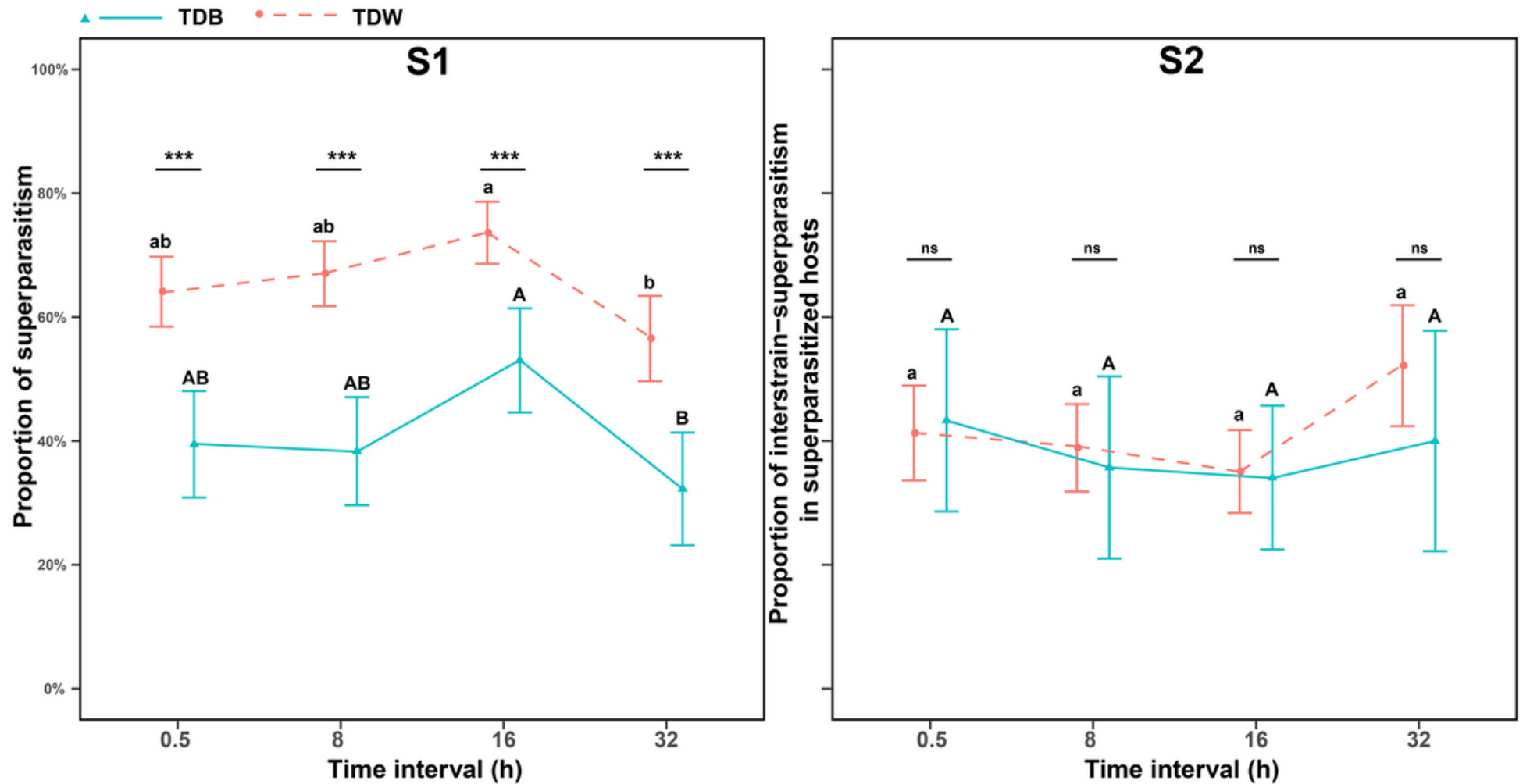

Figure 1

Proportion of superparasitism (S1) and inter-strain superparasitism (S2) as influenced by time interval and Trichogramma strain. Difference upper case letters indicate significant difference among different time interval of TDB females. Difference lower case letters indicate significant difference among different time

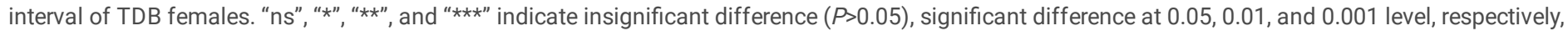
between TDB and TDW. 

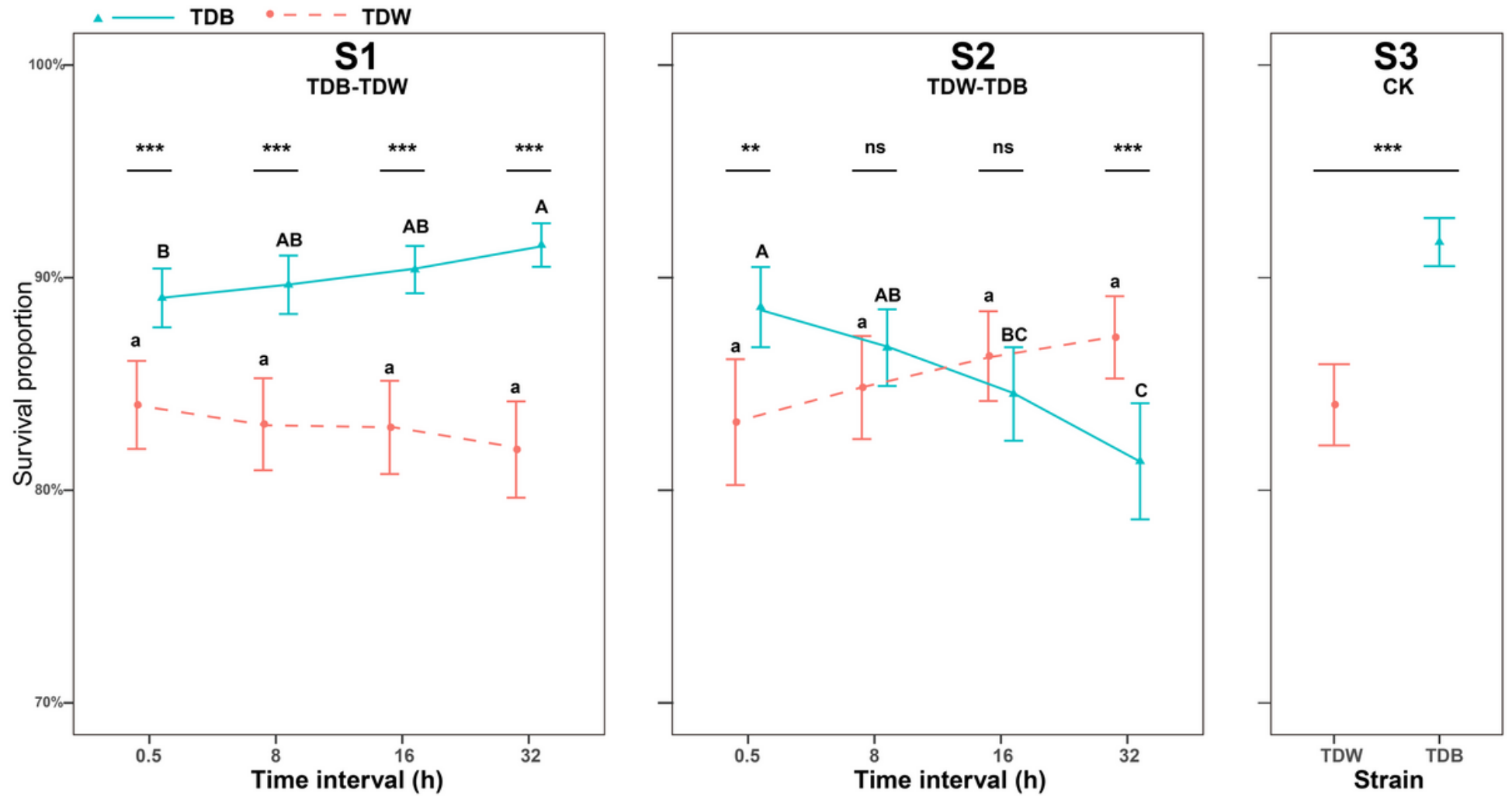

Figure 2

Survival proportion of Trichogramma offspring as influenced by order of parasitism, time interval, and Trichogramma strain (TDB-TDW: S1; TDW-TDB: S2); and the control group (S3). Difference upper case letters indicate significant difference among different time interval of TDB females. Difference lower case

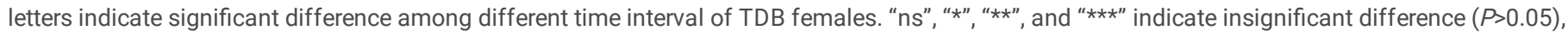
significant difference at $0.05,0.01$, and 0.001 level, respectively, between TDB and TDW. 

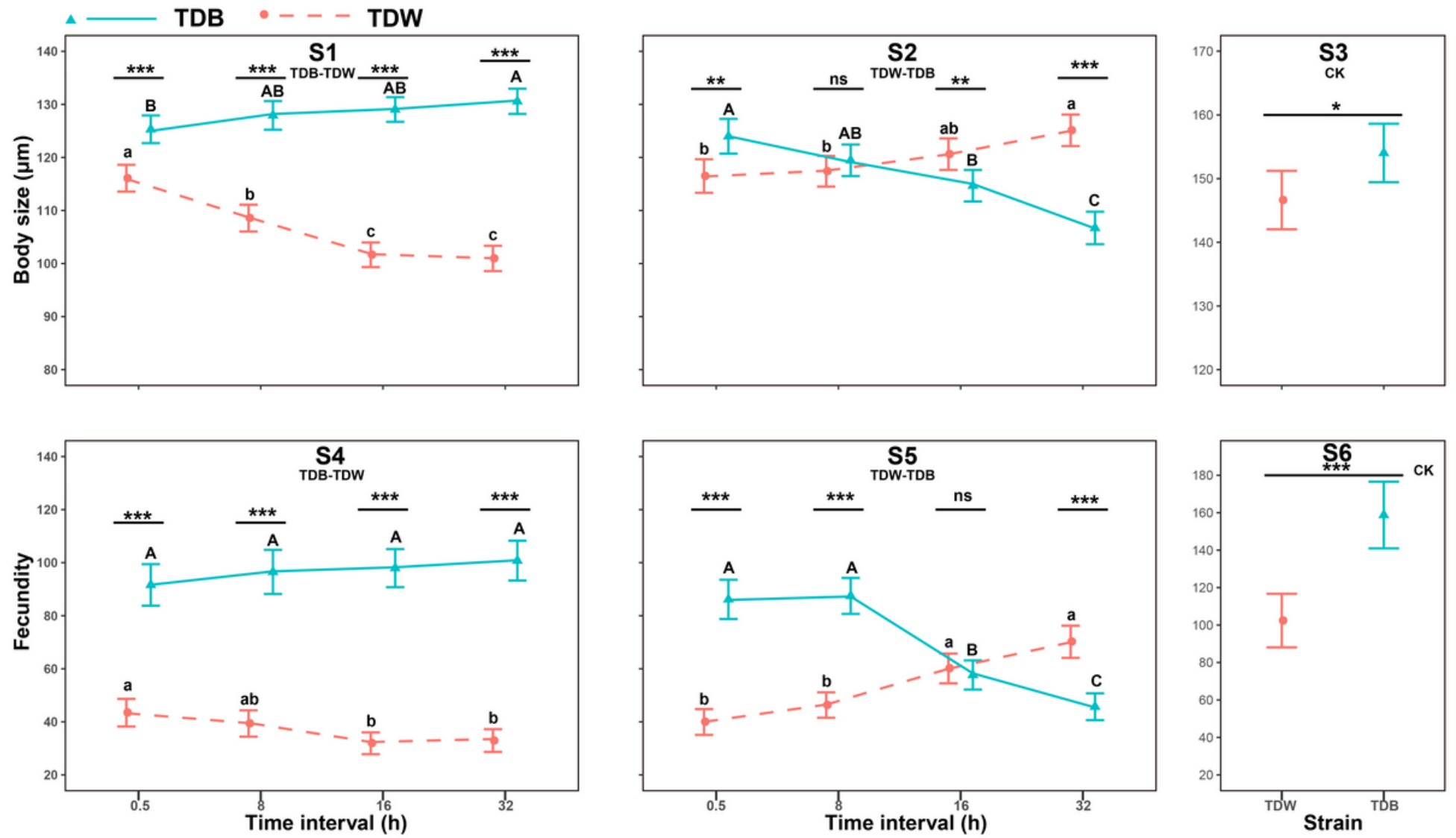

\section{Figure 3}

Body size (TDB-TDW: S1; TDW-TDB: S2; CK: S3) and fecundity (TDB-TDW: S4; TDW-TDB: S5; CK: S6) of Trichogramma offspring female as influenced by order of parasitism, time interval, and Trichogramma strain; and the control group. Difference upper case letters indicate significant difference among different time interval of TDB offspring females. Difference lower case letters indicate significant difference among different time interval of TDB offspring females.

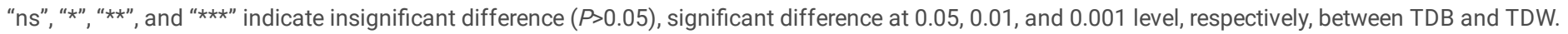



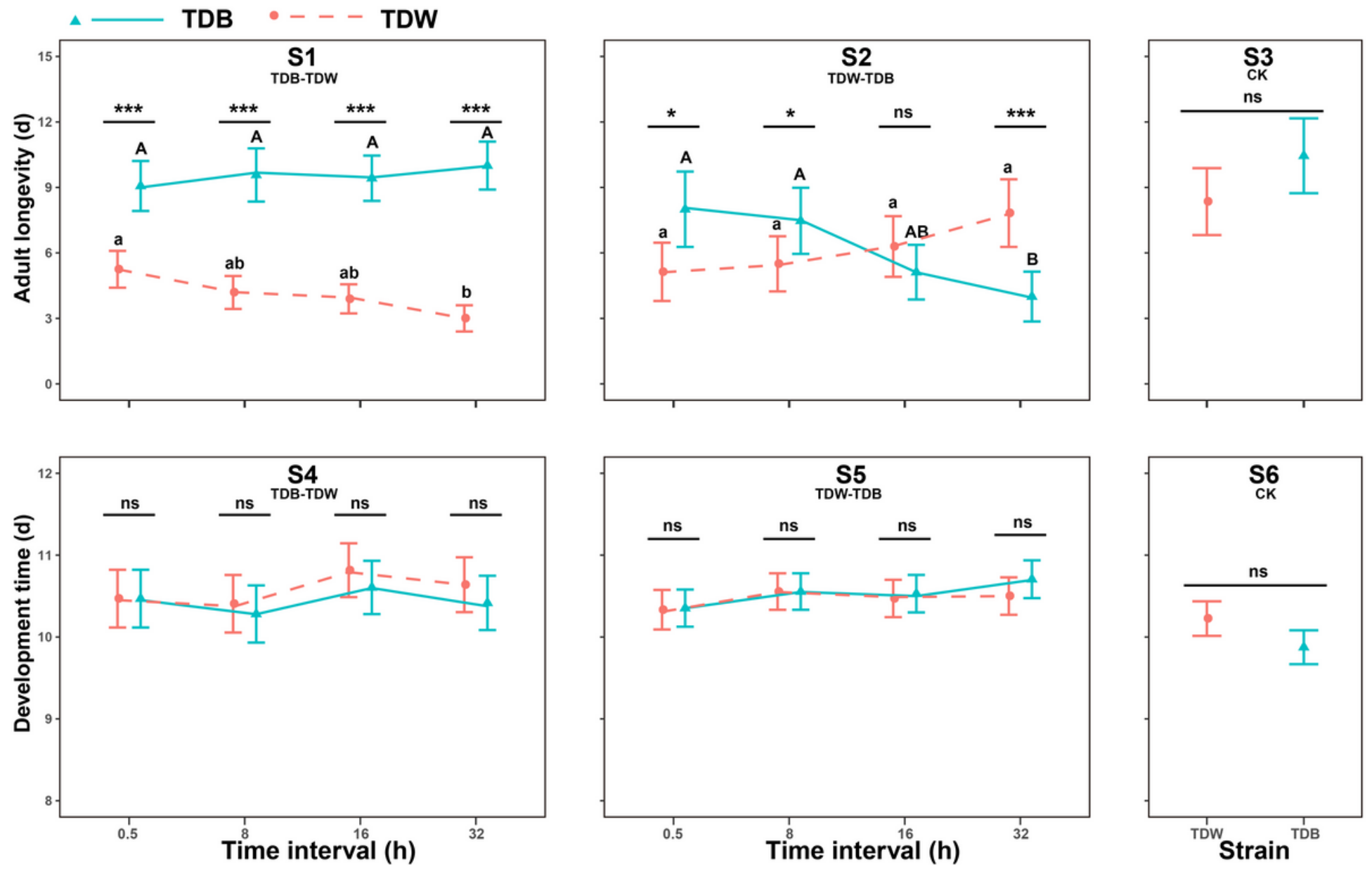

Figure 4

Adult longevity (TDB-TDW: S1; TDW-TDB: S2; CK: S3) and development time (TDB-TDW: S4; TDW-TDB: S5; CK: S6) of Trichogramma offspring as influenced by order of parasitism, time interval, and Trichogramma strain; and the control group. Difference upper case letters indicate significant difference among different time interval of TDB offspring. Difference lower case letters indicate significant difference among different time interval of TDB offspring. "ns", “*”,

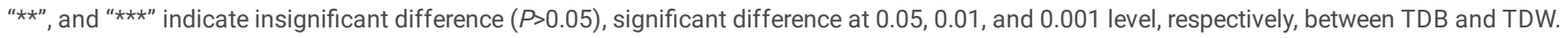




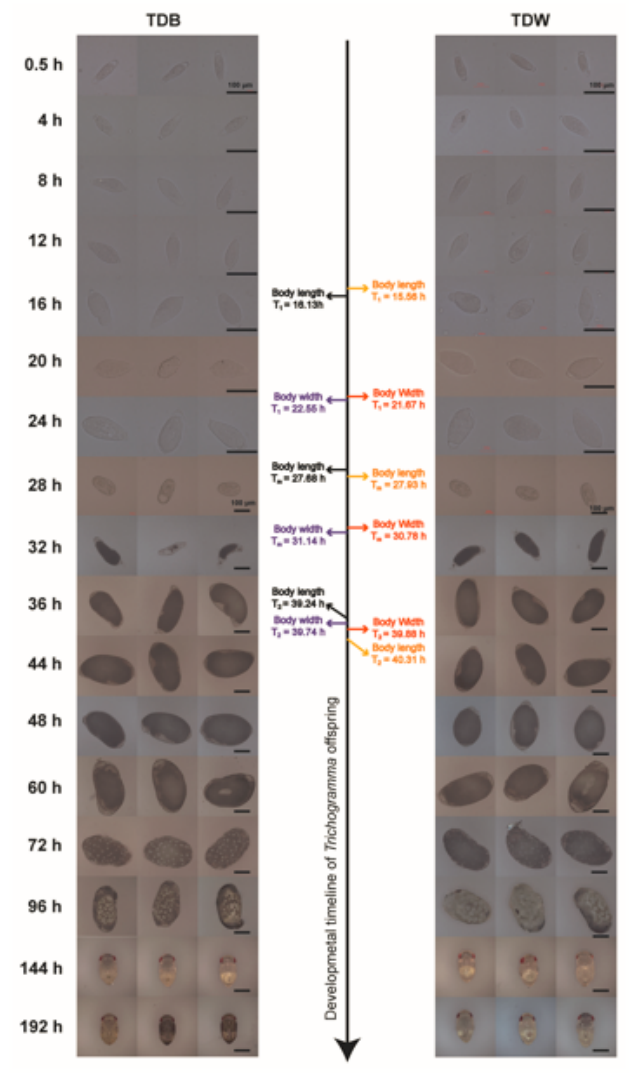

\section{Figure 5}

Images of immature stage of TDB (A) and TDW (B) offspring in single-parasitism at different developmental time.

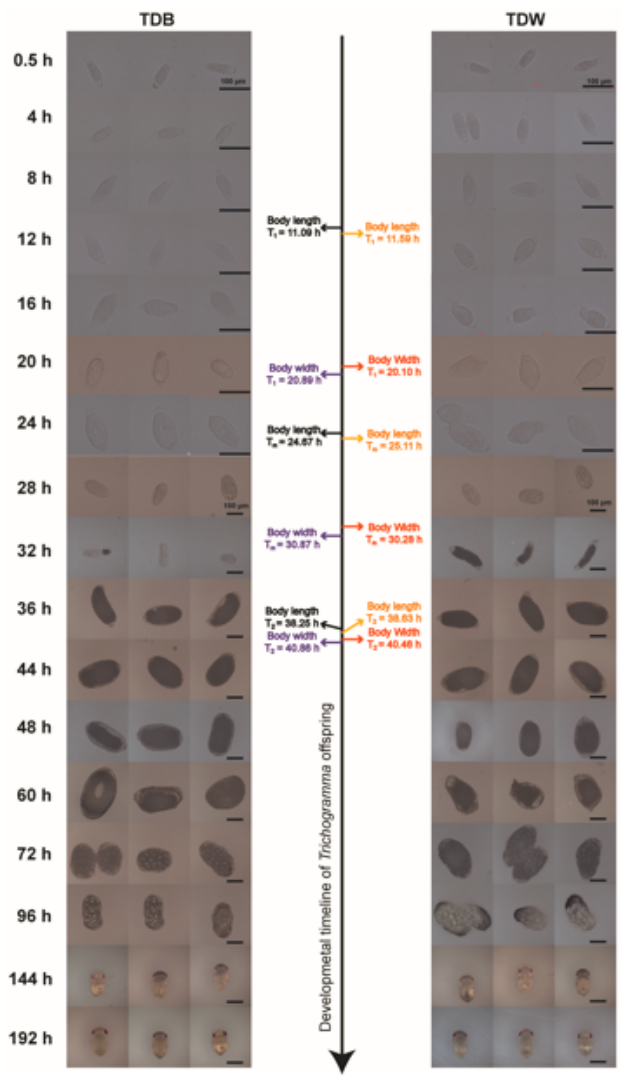

Figure 6 
Images of immature stage of TDB (A) and TDW (B) offspring in superparasitism at different developmental time.
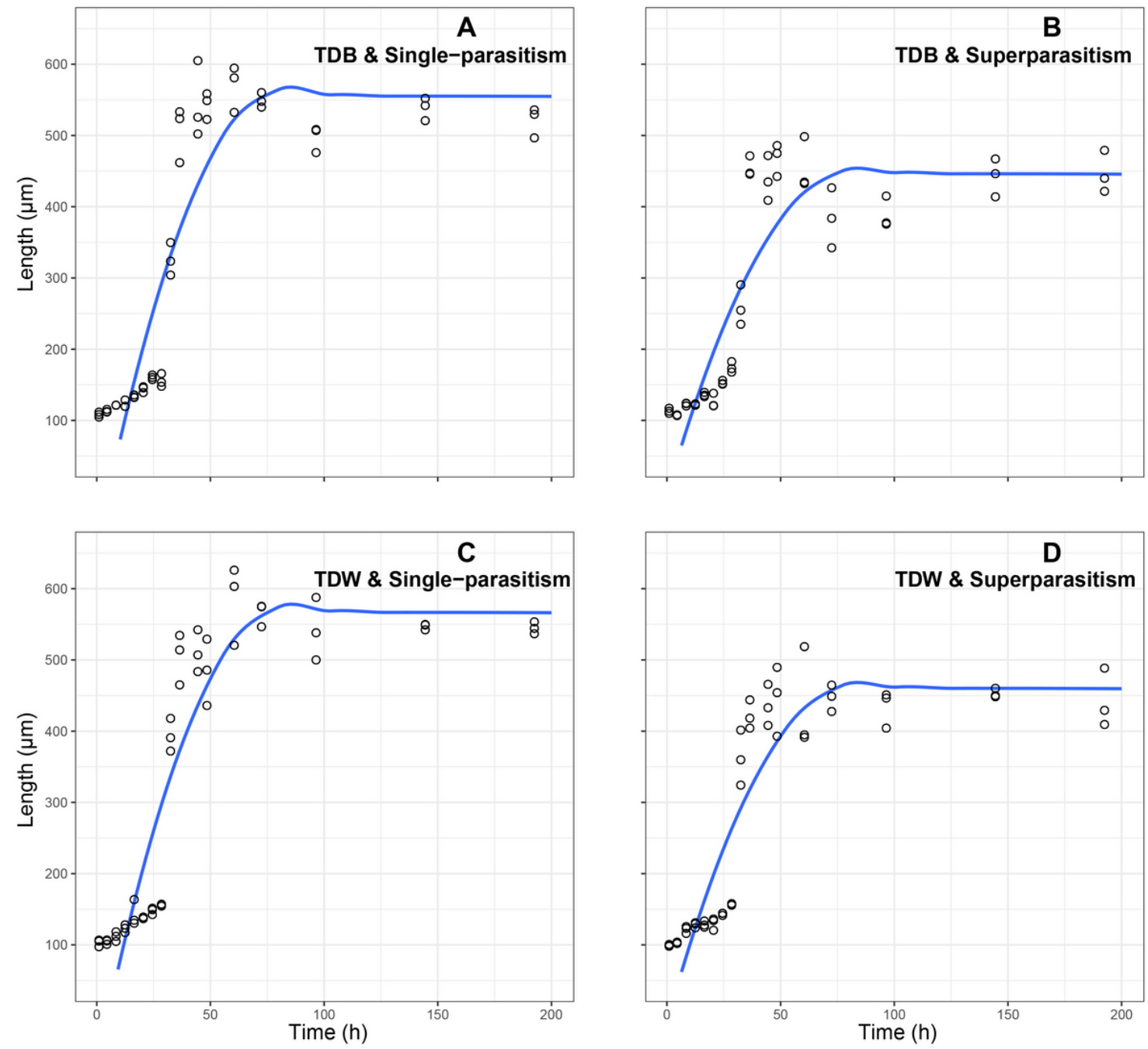

Figure 7

Length of immature offspring of TDB and TDW offspring as influenced by developmental time in single-parasitism (TDB: A; TDW: C) and superparasitism (TDB: B; TDW: D) 

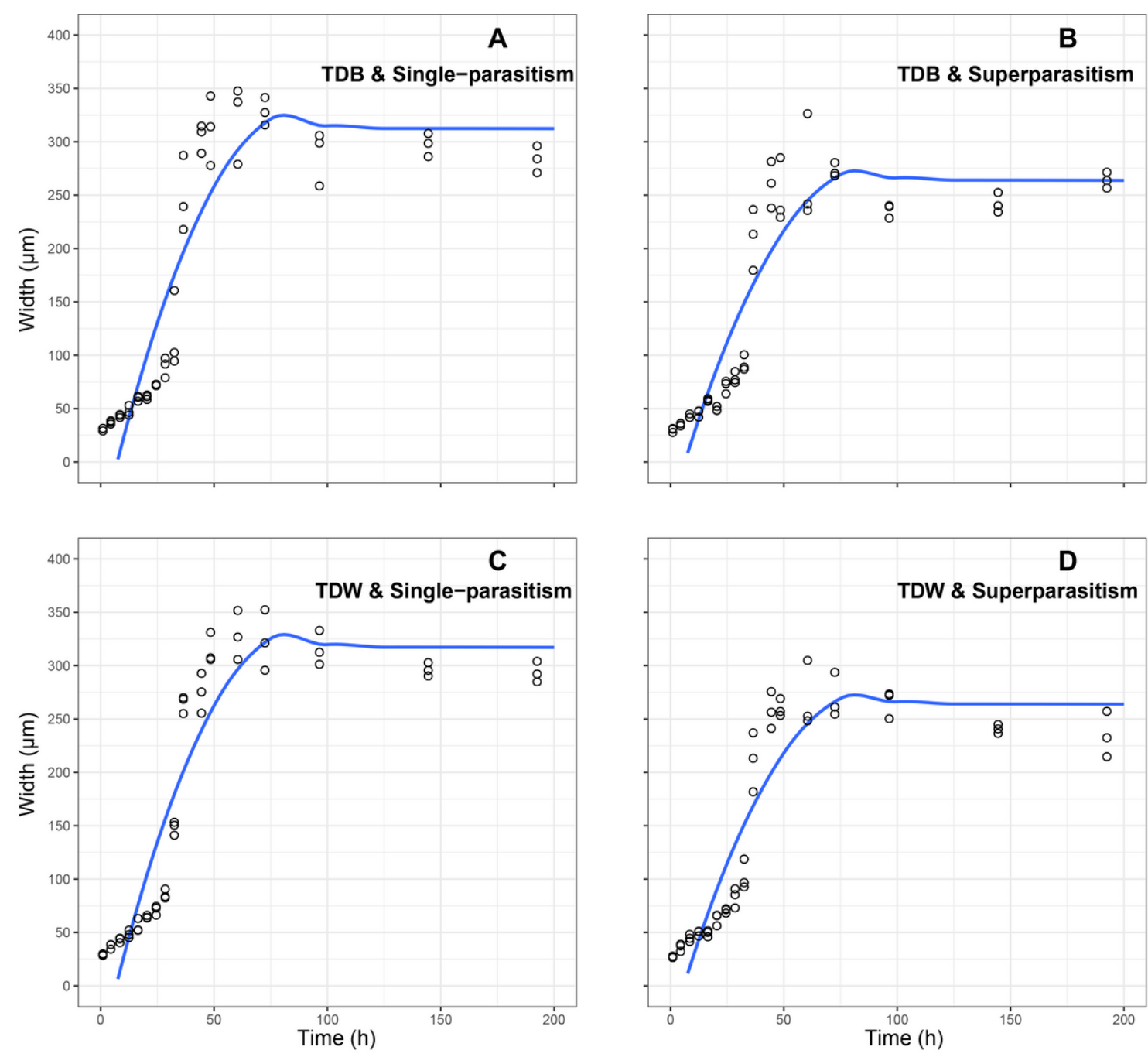

Figure 8

Width of immature offspring of TDB and TDW offspring as influenced by developmental time in single-parasitism(TDB: A; TDW: C) and superparasitism condition(TDB: B; TDW: D). Lines were fitted by logistic growth models. 